\title{
KEWENANGAN PEMERINTAH DAERAH TERHADAP ZONASI PENGELOLAAN WILAYAH PESISIR DAN PULAU PULAU KECIL DI PROVINSI KALIMANTAN UTARA
}

\author{
Nurul Ridwan Yusuf \\ Dinas Perpustakaan dan Kearsipan Provinsi Kalimanta Utara \\ aaoneridwan82@yahoo.com
}

\begin{abstract}
ABSTRAK
$\overline{\text { Kewenangan Pemerintah Daerah Terhadap Zonasi Pengelolaan Wilayah Pesisir Dan }}$ Pulau-pulau Kecil Di Provinsi Kalimantan Utara oleh Nurul Ridwan Yusuf dan dibimbing oleh Dr. Marthen B. Salinding, S.H., M.H dan Dr. Marthin Balang., S.H., M.Hum. Dalam penelitian ini, rumusan masalah yang diangkat antara lain: 1 . Kewenangan Pemerintah Daerah dalam Mengelola Sumberdaya Perikanan, 2. Upaya Pemerintah Daerah dalam meminimalisir konflik Pengelolaan Sumberdaya Perikanan di Provinsi Kalimantan Utara. Penelitian ini bertujuan untuk menguji secara normatif dan mengkaji isu hukum menggunakan prinsip hukum serta dengan menggunakan metodologi pendekatan peraturan perundang-undangan (statue approach) dan pendekatan kasus (case approach). dan disajikan dalam bentuk diskriptif analitik dengan menggambarkan hasil dari penelitian ini secara jelas sesuai dengan pendekatan yang dilakukan. Penelitian ini diharapkan dapat memecahkan kebuntuan dan kevacuman serta permasalahan atas kewenangan pemerintah daerah dalam pengelolaan sumberdaya perikanan berdasarkan kewenangan pemerintah provinsi Kalimantan utara, dengan rumusan masalah diantaranya tentang bagaimana implementasi kewenangan pemerintah provinsi Kalimantan utara dalam pengelolaan sumberdaya perikanan serta upaya pemerintah meminimalisir konflik pengelolaan sumberdaya perikanan. Dari hasil penelitian dapat disimpulkan bahwa konsep yang dilakukan masih bersifat sederhana dan cenderung berorientasi pada upaya memperoleh Pendapatan Asli Daerah (PAD) sehingga upaya percepatan untuk mensejahterahkan nelayan belum maksimal sebagaimana diharapkan. Terhadap kewenangan dalam pengelolaan sumberdaya perikanan pada pelaksanaannya tidak terjadi pelanggaran kewenangan akan tetapi pemerintah provinsi Kalimantan utara belum maksimal dalam memanfaatkan kewenangan yang telah diberikan untuk mensejahterahkan masyarakatnya, sedangkan terkait upaya meminimalisir konflik pengelolaan sumberdaya perikanan, pemerintah provinsi Kalimantan utara telah melakukan beberapa upaya akan tetapi upaya yang dilakukan lebih pada upaya meredam dan bersifat sementara tidak menyelesaikan permasalahan dan cenderung menimbulkan masalah diantaranya tumpang tindih daerah penangkapan ikan, kepastian hukum dan keadilan serta perlindungan bagi nelayan kecil/tradisional.
\end{abstract}

\section{Kata Kunci: Kepastian hukum, Batas Wilayah Pengelolaan, Keadilan dan Penyelesaian Konflik}

\footnotetext{
ABSTRACT

The authority to manage fisheries resources carried out by the regional government is in accordance with the division of functions authorized by the regional government of the province of North Kalimantan and has been carried out since regional autonomy began in the region. Until now, the concept of fisheries resource management carried out by the northern Kalimantan government is still simple and tends to be oriented towards efforts to obtain Local Revenue (PAD) so that the acceleration of efforts to prosper fishermen has not been maximized as expected. Regarding the authority in the management of fisheries resources in its implementation, there is no violation of authority, but the North
} 
Kalimantan provincial government has not been maximized in utilizing the authority that has been given to the welfare of its people. In an effort to minimize conflict over fisheries resource management, the North Kalimantan provincial government has made several efforts but the efforts made are more on efforts to reduce and temporarily not solve problems and tend to cause problems including overlapping fishing areas, legal certainty and justice and protection for small fishermen /traditional.

\section{Keywords: conflict, fisheries resources}

\section{PENDAHULUAN}

Provinsi Kalimantan Utara (Kaltara) adalah sebuah provinsi termuda di Indonesia yang terletak di bagian utara Pulau Kalimantan. Secara geografis, Provinsi ini berbatasan langsung dengan negara tetangga, yaitu Negara Bagian Sabah dan Serawak, Malaysia Timur di bagian utara dan berbatasan dengan Provinsi Kalimantan Timur di bagian Selatan. Sedangkan di bagian Timur berbatasan dengan Laut Sulawesi. Provinsi Kalimantan Utara memiliki luas $\pm 75.467,70$ km2, sementara berdasar batas kewenangan provinsi, luas lautan mencapai $11.579 \mathrm{~km} 2$ (13\% dari luas wilayah total). Terletak pada posisi antara $01{ }^{\circ} 00^{\prime} 00^{\prime \prime}-04 \circ 30^{\prime} 00^{\prime \prime} \mathrm{LU}$ dan114॰30’00"-118॰30’00”BT.

Pulau-pulau kecil di Provinsi Kaltara terletak di Kabupaten Nunukan, Bulungan, Tana Tidung dan Kota Tarakan. Jumlah pulau-pulau kecil di Provinsi Kaltara adalah 161 pulau dengan luas total mencapai 3.597 km2. Pulau-pulau terbesar yaitu Pulau Tarakan (249 km2), Pulau Sebatik (245 m2), Pulau Nunukan (233 km2), dan Pulau Tanah Merah (352 km2). Sementara panjang garis pantai provinsi ini adalah $3.955 \mathrm{~km}, 908 \mathrm{~km}$ (23\%) merupakan garis pantai daratan dan $3.047 \mathrm{~km}(77 \%)$ merupakan garis pantai kepulauan.

Pengelolaan dan pemanfaatan sumberdaya wilayah pesisir dan pulau-pulau kecil Provinsi Kalimantan Utara menghendaki adanya keberlanjutan (sustainability), mengingat wilayahnya terdapat beraneka ragam sumberdaya yang memungkinkan pemanfaatan secara berganda. Dari itu pengelolaan harus secara terpadu dan berkesinambungan (sustainable) karena memiliki nilai strategis yakni potensi sumberdaya alam dan jasa-jasa lingkungan yang kaya dan beragam. Besar serta beragamnya potensi tersedia memberikan motivasi kepada para pemangku kepentingan (stakeholders) untuk mengoptimalisasi secara rasional dan bertanggung jawab dalam pemanfaatannya. Oleh karena itu perlu ada kesatuan wawasan pengelolaan dan pemanfaatan sumber daya pesisir dan pulau-pulau kecil melalui perencanaan yang rasional dan terintegrasi antara sektor dan pemangku kepentingan, diwujudkan dalam rencana zonasi yang menentukan arah penggunaan sumber daya tiap-tiap satuan perencanaan disertai dengan penetapan struktur dan 
pola ruang pada kawasan perencanaan yang memuat kegiatan yang boleh dilakukan dan tidak boleh dilakukan serta kegiatan yang hanya dapat dilakukan setelah memperoleh izin. Serta pemberian sanksi terhadap pelanggaran yang dilakukan dalam pemanfaatannya.

Berdasarkan ketentuan tersebut, pemerintah Provinsi Kalimantan Utara kemudian mengeluarkan Peraturan Daerah Provinsi Kalimantan Utara Nomor 4 Tahun 2018 tentang Rencana Zonasi Wilayah Pesisir dan Pulau-Pulau Kecil Provinsi Kalimantan Utara Tahun 2018-2038. Keluarnya peraturan daerah ini, menjadi isu penelitian adalah seputar kewenangan yuridis pemerintah Provinsi Kalimantan Utara untuk membentuk peraturan daerah yang mengatur secara spesifik tentang Zonasi Wilayah Pengelolaan Pulau Pulau Kecil.

\section{METODE PENELITIAN}

Penelitian ini merupakan penelitian hukum normative yang digunakan adalah pendekatan undang undang (statute approach) yang menelaah undang undang dan regulasi menyangkut pengelolaan sumber daya perikanan dan kewenangan pemerintah daerah provinsi kalimantan utara didalam pengelolaan sumberdaya perikanan. Selanjutnya didalam penelitian ini digunakan juga pendekatan kasus (case approach), yang menelaah terhadap kasus kasus yang berkaitan dengan isu, yaitu tentang kewenangan pemerintah daerah provinsi terhadap pengelolaan sumberdaya perikanan. Sumber Bahan Hukum yang dianalisis adalah sumber bahan hokum primer dan sekunder, sumber bahan hukum primer merupakan bahan hukum yang bersifat autoritatif artinya mempunyai otoritas, bahan hukum primer terdiri dari perundang-undangan, catatan-catatan resmi atau risalah dalam pembuatan perundang-undangan dan putusan-putusan hakim. Bahan hukum primer dalam penelitian ini antara lain adalah

a) Undang Undang Dasar 1945,

b) Undang-Undang Nomor 31 Tahun 2004 tentang Perikanan,

c) Undang-Undang Nomor 23 Tahun 2014 tentang Pemerintahan Daerah,

d) Undang-Undang Nomor 27 Tahun 2007 tentang Pengelolaan Wilayah Pesisir dan Pulau-Pulau Kecil,

e) Peraturan Menteri Kelautan dan perikanan Nomor : 06 tahun 2008 tentang Penggunaan Pukat Ikan di Perairan Kalimantan Timur bagian Utara,

f) Peraturan perundang-undangan, yang terkait dengan penelitian dan kesepakatan/perjanjian yang telah disepakati bersama. Sedangkan bahan-bahan 
hukum sekunder berupa semua publikasi tentang hukum yang bukan merupakan dokumen-dokumen resmi, publikasi tentang hukum meliputi bukubuku teks, kamus hukum, jurnal-jurnal hukum dan komentar-komentar atas putusan pengadilan, hasil penelitian hokum yang relevan, serta sumber lainya dari internet

\section{HASIL PENELITIAN DAN PEMBAHASAN}

\section{A. Pembagian Kewenangan antara Pemerintah dengan Pemerintah Daerah}

Diberlakukannya Otonomi Daerah memberikan semangat baru bagi daerah, sejak dikeluarkannya Undang Undang Nomor 20 Tahun 2012 sampai dengan selanjutnya merevisi Undang Undang Nomor 32 tahun 2004 dengan Undang-Undang 23 Tahun 2014, pengelolaan sumberdaya alam menjadi isu strategis dan sebagai bagian yang melandasi semangat otonomi daerah, Didalam Undang Undang 23 Tahun 2014 tentang Pemerintahan Daerah, pembagian urusan yang menjadi kewenangan pemerintahan daerah provinsi tertuang dalam Pasal 13 ayat (3), sedang urusan yang diserahkan dan menjadi wewenang pemerintahan daerah kabupaten/kota, tercantum dalam Pasal 13 ayat (4), sebagaimana disebutkan : (3) Berdasarkan prinsip sebagaimana dimaksud pada ayat (1) kriteria Urusan Pemerintahan yang menjadi kewenangan Daerah provinsi adalah:

a. Urusan Pemerintahan yang lokasinya lintas Daerah kabupaten/kota;

b. Urusan Pemerintahan yang penggunanya lintas Daerah kabupaten/kota;

c. Urusan Pemerintahan yang manfaat atau dampak negatifnya lintas Daerah kabupaten/kota; dan/atau

d. Urusan Pemerintahan yang penggunaan sumber dayanya lebih efisien apabila dilakukan oleh Daerah Provinsi.

Berdasarkan prinsip sebagaimana dimaksud pada ayat (1) kriteria Urusan Pemerintahan yang menjadi kewenangan Daerah kabupaten/kota adalah :

a. Urusan Pemerintahan yang lokasinya dalam Daerah kabupaten/kota;

b. Urusan Pemerintahan yang penggunanya dalam Daerah kabupaten/kota;

c. Urusan Pemerintahan yang manfaat atau dampak negatifnya hanya dalam Daerah kabupaten/kota; dan/atau

d. Urusan Pemerintahan yang penggunaan sumberdayanya lebih efisien apabila dilakukan oleh Daerah kabupaten/kota." 
Lebih lanjut pembagian urusan pemerintahan daerah yang menjadi kewenangan pemerintah daerah provinsi dan pemerintah daerah kabupaten/kota, diatur dalam Peraturan Pemerintah Republik Indonesia Nomor 38 tahun 2007 tentang Pembagian Urusan Pemerintah antara Pemerintah, Pemerintah Daerah Provinsi dan Pemerintah Daerah Kabupaten/Kota ${ }^{1}$, dalam bentuk urusan wajib dan urusan pilihan, terkait dengan kewenangan pengelolaan sumberdaya alam yang menjadi kewenangan pemerintah daerah, tertuang dalam Peraturan Pemerintah RI Nomor 38 tahun 2007 tentang Pembagian Urusan Pemerintah antara Pemerintah, Pemerintah Daerah Provinsi dan Pemerintah Daerah Kabupaten/Kota, pada Pasal 7 ayat (3) dan (4), disebutkan : "(3) Urusan pilihan sebagaimana dimaksud dalam Pasal 6 ayat (2) adalah urusan yang secara nyata ada dan berpotensi untuk meningkatkan kesejahteraan masyarakat sesuai dengan kondisi, kekhasan, dan potensi unggulan daerah yang bersangkutan.(4)Urusan pilihan sebagaimana dimaksud pada ayat (3), meliputi :
a. Kelautan dan Perikanan;
b. Pertanian;
c. Kehutanan;
d. energi dan sumber daya mineral;
e. Pariwisata;
f. Industri;
g. Perdagangan; dan
h. Ketransmigrasian."

\section{B. Kewenangan Pemerintah Daerah Dalam Pengelolaan Sumber Daya}

\section{Alam}

Kewenangan pemerintah daerah dalam mengatur dan mengurus pengelolaan sumberdaya alam, sesuai amanat undang-undang dimulai sejak pertama kali diberlakukannya undang undang otonomi daerah (UU Nomor 22 tahun 1999 tentang pemerintahan daerah) hingga ke hasil revisi UU Nomor 32 Tahun 2004 tentang Pemerintahan Daerah, pelaksanaan otonomi daerah yang kurang lebih sudah berjalan 12 tahun ( 1999 - 2011) menampil beberapa undang undang yang mengatur dalam pengelolaan sumberdaya alam yang sedikit banyaknya dilakukan oleh pemerintah

1 Peraturan Pemerintah Republik Indonesia Nomor 38 tahun 2007 tentang Pembagian Urusan Pemerintah antara Pemerintah, Pemerintah Daerah Provinsi dan Pemerintah Daerah Kabupaten/Kota. Lembaran Negara Republik Indonesia Tahun 2007 Nomor 82. Tambahan Lembaran Negara Republik Indonesia Nomor 4737 
daerah, beberapa sumberdaya alam yang diatur dan menjadi kewenangan daerah diantaranya ; sumberdaya kelautan dan perikanan, sumberdaya pertanian, sumberdaya kehutanan, dan sumberdaya energy dan mineral, sedangkan Undang Undang yang mengatur pengelolaan sumberdaya alam terkait dengan semangat dari otonomi daerah diantaranya ; UU Perikanan, UU Perkebunan, UU Kehutanan dan UU Sumberdaya Air. Diantara undang undang tersebut, bukanlah undang undang baru akan tetapi seiring dengan semangat otonomi daerah UU yang sebelumnya ada direvisi untuk mendampingi UU otonomi daerah, seperti Undang Undang Nomor 31 Tahun 2004 Tentang Perikanan, yang merupakan pengganti dari Undang Undang Nomor 9 Tahun 1985 tentang Perikanan,

Kewenangan pemerintah daerah provinsi Kalimantan utara dalam mengelola sumberdaya alam termasuk didalamnya sumberdaya perikanan sebagaimana yang diamanatkan dalam undang undang otonomi pada umum masih bersifat terbatas dan masih terikat pada aturan perundang undang lainnya yang mengatur secara teknis namun tidak memberikan kejelasan kewenangan daerah termasuk didalam melindungi masyarakat nelayan tradisional/kecil dalam memanfaatkan sumberdaya perikanan di wilayah laut.

Meski Undang Undang Nomor 23 Tahun 2014, memberikan kewenangannya terhadap daerah, baik kewenangan atas wilayah maupun kewenangan kegiatan yang dilakukan serta kewenangan atas urusan pemerintahan, akan tetapi kewenangan tersebut masih terbelenggu oleh aturan perundang-undangan yang lebih khusus.

\section{Kewenangan Pengelolaan Sumberdaya Perikanan di Daerah}

Didalam UU Nomor 23 tahun 2014 menyebutkan bahwa daerah Provinsi diberikan kewenangan untuk mengelola wilayah laut sepanjang 12 (dua belas) mil yang diukur dari pasang surut air laut terendah. Sehingga dapat dimaknai bahwa kewenangan pemerintah daerah Provinsi Kalimantan Utara secara administrasi dalam mengelola sumberdaya perikanan diwilayah laut dibatasi pada wilayah laut 12 (dua belas) mil. Pada wilayah tersebut pemerintah daerah Provinsi diberikan kewenangan untuk mengelola sumber daya di wilayah laut sebagaimana tercantum didalam Undang Undang Nomor 23 tahun 2014 Pasal 27 ayat (1), menyebutkan : "Daerah yang memiliki laut diberikan kewenangan untuk mengelola sumber daya di wilayah laut"

Sesuai dengan kewenangan yang diberikankan diatas maka kewenangan daerah tersebut secara eksplisit mencakup pada kewenangan pengelolaan sumberdaya perikanan yang secara langsung atau dimaknai pada pemanfaatan dan pemulihan 
sumberdaya perikanan merujuk pada huruf $a$ yaitu eksplorasi, eksploitasi, konservasi dan pengelolaan kekayaan laut, sedangkan pada huruf $b$ sampai dengan $d$, diarahkan pada pembinaan, pengendalian dan penataan terhadap pemanfaatan dan pemulihan sumberdaya perikanan, sedangkan pada huruf e dan f, diarahkan pada seluruh potensi sumberdaya perikanan dapat menjadi potensi pendukung keamanan wilayah dan kedaulatan Negara.

\section{Implementasi Kewenangan Pemerintah Daerah Provinsi Kalimantan Utara dalam Pengelolaan Sumber Daya Perikanan}

Sebagai provinsi baru, Kalimantan utara dikelililngi laut yang memiliki potensi perikanan demikian besar, baik perikanan tangkap maupun perikanan budidaya, kegiatan penangkapan ikan yang dilakukan nelayan dapat mencapai wilayah laut Sulawesi bahkan wilayah perbatasan dengan Malaysia dan Philipina. Sedangkan kegiatan perikanan budidaya berupa budidaya udang dan ikan melalui kegiatan pertambakan, selain hal tersebut pada 5 (lima) tahun terakhir kegiatan budidaya dilaut melalui kegiatan budidaya rumput laut kian marak dan berkembang pesat. Potensi sumberdaya yang ada saat ini mendukung perkembangan dan tumbuhnya sektor perdagangan dan industry perikanan, diantaranya perusahan pembekuan produk perikanan (coldstorage) yang menjadikannya komuditi perikanan yang ada menjadi komuditi eksport.

Dari hal diatas, kewenangan pengelolaan sumberdaya perikanan yang dilakukan pemerintah daerah sesuai dengan pembagian urusan yang diwenangkan kepemerintah daerah provinsi Kalimantan utara dan dilaksanakan sejak otonomi daerah bergulir didaerah, diantaranya :

1. Perencanaan dan penataan ruang wilayah laut dan pesisir merupakan kegiatan pemerintah dalam mengimplemetasi kewenangannya melalui penataan wilayah laut termasuk pesisir yang merupakan bagian yang saling bersinggungan dan memberikan pengaruh besar terhadap sumberdaya perikanan diwilayah laut provinsi Kalimantan utara.

2. Kegiatan Pelayanan perizinan Usaha Perikanan mencakup perizinan usaha perikanan tangkap, perikanan budidaya dan pengolahan hasil perikanan yang diarahkan sebagai upaya pengendalian dan pembinaan kegiatan masyarakat dalam memanfaatkan sumberdaya perikanan.

3. Kegiatan pembinaan usaha perikanan melalui kegiatan pembinaan mutu hasil perikanan, mutu hasil tangkapan dan mutu hasil budidaya selain hal tersebut atas kewenangan yang dimiliki pemerintah daerah melakukan 
pembinaan usaha dalam upaya mengoptimalkan produksi dan kualitas hasil perikanan.

4. Kegiatan konservasi dan keberlanjutan sumberdaya perikanan melalui upaya restocking benih ikan dan penyu serta pemasangan rumpon diwilayah perairan provinsi Kalimantan utara dan sekitarnya.

5. Kegiatan pengawasan perikanan merupakan upaya pemerintah daerah melaksanakan kewenagannya bagi memberikan perlindungan dan kepastian hukum bagi masyarakat pemanfaat sumberdaya perikanan sesuai dengan peraturan perundang-undangan yang telah ditetapkan.

6. Upaya pemberdayaan masyarakat nelayan melalui peningkatan usaha, motorisasi dan perbaikan alat tangkap serta penyertaan masyarakat didalam pengawasan sumberdaya perikanan dan peningkatan partispasi didalam perencanaan pembangunan kelautan dan perikanan di provinsi Kalimantan utara.

Beberapa upaya tersebut merupakan bagian dari kewenangan yang didelegasikan kepemerintah provinsi Kalimantan utara, akan tetapi semua kewenangan tersebut dapat dijalankan sebagaimana mestinya, masih banya kewenangan yang semestinya dapat dikembangkan dan dimaksimalkan namun terdapat kendala khususnya adanya peraturan perundang-undangan yang dikeluarkan pemerintah menjadi kewenangan tersebut tidak maksimal.

\section{E. Konsep Pengelolaan Sumberdaya Perikanan Berdasarkan Kewenangan Pemerintah Daerah}

\section{Prinsip Prinsip Pengelolaan Sumberdaya Perikanan}

Didalam pengelolaan dan pemanfaatan sumberdaya perikanan di era otonomi daerah, konsep pengelolaan sumberdaya perikanan merupakan kerangka acuan bagi penyelenggara pemerintahan didaerah untuk mengelola sumberdaya alam yang ada diwilayah laut khususnya sumberdaya perikanan, sehingga ada arah yang jelas baik dari segi pemanfaatannya terhadap masyarakat maupun kesinambungan sumberdaya tersebut, konsep yang ada dapat dijadikan arah dan tujuan sekaligus sebagai pengendali didalam melakukan pengelolaan sumberdaya perikanan. Untuk melakukan pengelolaan sumberdaya perikanan sebagaimana diharapkan maka konsep pengelolaan sumberdaya perikanan hendaknya mempertimbangkan beberapa prinsip- 
prinsip2, sebagai berikut : a. Prinsip Kelestarian Sumberdaya Perikanan. b. Prinsip Keseimbangan antara Pemanfaatan dan pemulihan. c. Prinsip Ekonomi. d. Prinsip Partisipasi. e. Prinsip akuntabilitas dan Transparansi. f. Prinsip keterpaduan. g. Prinsip Persatuan dan kesatuan.

\section{Tahapan Pengelolaan Sumberdaya Perikanan}

Pengelolaan sumberdaya perikanan yang dilakukan diharapkan agar dapat meningkatkan kesejatreaan masyarakat, sehingga pengelolaan dapat diarahkan pada pengoptimalan pemanfaatan sumberdaya perikanan dan pengendalian serta keberlanjutan sumberdaya perikanan tersebut. Berdasarkan hal tersebut diperlukan suatu kegiatan yang terencana dan saling menunjang satu dengan lainnya, sehingga dapat dihasilkan suatu pengelolaan yang terpadu untuk memperoleh pengelolaan yang optimal dan berkelanjutan. Sejalan dengan semangat otonomi daerah, yang mana pemerintah daerah selaku penyelenggara pemerintahaan didaerah maka konsep pengelolaan sumberdaya perikanan hendak dapat berjalan sesuai dengan kewenangan yang diatur dalam peraturan perundang-undangan, untuk hal tersebut dibutuhkan konsep pengelolaan sumberdaya perikanan, dengan melalui tahapan penyusunan rencana sebagai berikut ${ }^{3}$ :

a. Penentuan batas; meliputi penentuan batas kewenangan daerah dan batas kewenagan pengelolaan.

b. Identifikasi potensi lokal ; meliputi potensi sumberdaya perikanan, potensi ekonomi, potensi sosial dan kelembagaan lokal, dan isu-isu pengelolaan.

c. Penetapan kebijakan pengelolaan meliputi kebijakan investasi, kebijakan perpajakan, pengawasan dan kelembagaan.

d. Menetapkan zonasi secara partisipatif.

e. Menetapkan pola pemanfaatan.

f. Menyusun program aksi.

g. Monitoring dan evaluasi

Tahapan yang disebutkan diatas merupakan bagian dari konsep pengelolaan sumberdaya perikanan yang dilakukan pemerintah daerah berdasarkan kewenangan pemerintah daerah provinsi dan kabupaten/kota dalam hal ini yang perlu dilakukan pemerintah provinsi Kalimantan utara dalam pengelolaan sumberdaya perikanan.

${ }^{2}$ Arif Satria., et.al. I., Op.cit, h. 7

${ }^{3}$ Arif satria, et.al., I., ibid. h.11 


\section{Pengelolaan sumberdaya perikanan yang berkelanjutan}

Pembangunan berkelanjutan (tambahan penulis) merupakan pembangunan untuk memenuhi kebutuhan hidup ini tanpa merusak atau menurunkan kemampuan generasi mendatang untuk memenuhi kehidupan hidupnya (WCED,1987). ${ }^{4}$ Dengan demikian, pembangunan berkelanjutan pada dasarnya merupakan suatu startegi pembangunan yang memberikan semacam batasan (limit) pada laju pemanfaatan ekositem dan sumberdaya perikanan yang terkandung didalamnya. Batasan yang ada tidaklah mutlak (absolute), melainkan berupakan batasanan yang flexible tergantung pada kondisi teknologi dan sosial ekonomi didalam pengelolaan dan pemanfaatan sumberdaya perikanan, serta kemampuan alam untuk menerima dampak dari kegiatan manusia. Dengan demikian pengelolaan yang pembangunan perikanan yang bersifat kelanjutan menjadi strategi yang memanfaatkan ekosistem yang ada dialam sedemikian rupa atau diolah sebaik-baiknya, sehingga potensi yang ada diwilayah laut memberikan manfaat bagi kehidupan masyarakat.

\section{Pengelolaan sumberdaya perikanan berbasis partispasi masyarakat}

Pengelolaan sumberdaya perikanan sebagaimana diamanatkan undang undang nomor 23 tahun 2014 otonomi daerah yang selanjutanya diuraikan didalam peraturan daerah provinsi Kalimantan utara nomor 4 tahun 2018 tentang rencana zonasi pengelolaan wilayah pesisir dan pulau pulau kecil, bahwa pengelolaan wilayah laut merupakan kewenangan yang didelegasikan kepada pemerintah provinsi kedalam satu urusan pilihan yang terkaver didalam undang undang 23 tahun 2014 tentang pemerintahan daerah. Sebagai bagian yang diberi wewenang maka pengelolaannya hendak secara konsisten dapat dilakukan pemerintah daerah dalam hal ini pemerintah provinsi Kalimantan utara.

Sebagaimana konsep pengelolaan yang seharusnya maka pengelolaan sumberdaya perikanan hendaknya memberikanan manfaat dan keadilan bagi masyarakat, sehingga keterlibatan masyarakat didalam proses pembuatan, pelaksanaan hingga pada pengawasan dan pengendalian dapat dilibatkan agar apa yang pencapaian pengelolaan sumberdaya alam perikanan yang maksimal perlu pelibatan masyarakat secara utuh khususnya masyarakat nelayan dan masyarakat yang bermukim disekitar wilayah pesisir dan pulau-pulau kecil. Menurut Sudirman yang mengutip pendapat Dutton dan Soebondro menyatakan bahwa partisipasi

${ }^{4}$ Rokhmin Dahuri,.Op.cit.,h. 153 
pengguna sumberdaya alam didalam perencanaan, memperhatikan serius karena dua hal. Pertama, ketiadaan partisipasi pengguna sumberdaya telah menyebabkan terjadinya penurunan kualitas ekosistem pantai secara umum. Kedua, meningkatnya konflik di antara pengguna sumberdayalah yang merupakan faktor penentu utama kesuksesan perencana sumberdaya. 5

Partispasi dan peran serta masyarakat didalam pengelolaan sumberdaya perikanan disebutkan dalam undang undang perikanan nomor 31 tahun 2004, pada Pasal 6 ayat (2), sebagai berikut : "Pengelolaan perikanan untuk kepentingan penangkapan ikan pembudidayaan ikan harus memperhatikan kepentingan adat dan atau kearifan lokal serta memperhatikan peran serta masyarakan".

\section{F. Konflik-Konflik Dalam Pengelolaan Sumberdaya Perikanan}

Pada era otonomi daerah persoalan konflik dalam pengelolaan dan pemanfaatan sumberdaya perikanan di wilayah laut merupakan persoalan yang sering terjadi bahkan konflik tersebut mengakibat timbulnya permasalah baru dan hal tersebut dapat menghambat upaya peningkatan kesejahteraan masyarakat dan upaya peningkatan pembangunan di daerah. Berdasarkan kajian yang telah dilakukan secara empiris konflik yang terjadi umumnya diawali oleh konflik sosial nelayan, yang dibagi kedalam kategori ${ }^{6}$, sebagai berikut : a. Konflik kelas merupakan konflik yang terjadi antar kelas sosial nelayan akibat dominasi usaha bermodal dan usaha tradisional, hal ini dapat ditemukan dibeberapa daerah tidak hanya di kab/kota provinsi dalam bentuk konflik antara nelayan trawl atau purse seine (kelas atas) dan nelayan kecil (kelas bawah) umumnya konflik tersebut terjadi akibat pengoperasian kapal trawl pada perairan pesisir yang merupakan wilayah penangkapan nelayan tradisional. b. Konflik orientasi merupakan konflik yang terjadi antar nelayan yang memiliki perbedaan orientasi dalam pemanfaatan sumberdaya perikanan, yaitu antara nelayan yang memiliki orientasi jangka panjang dengan nelayan yang berorientasi jangka pendek. Orientasi jangka panjang nelayan diwujudkan dalam bentuk kepedulian terhadap caracara pemanfaatan sumberdaya yang ramah lingkungan, umumnya nelayan ini masih diikat nilai-nilai tradisonal setempat bahwa sumberdaya perlu dijaga kelestariannya. Sementara itu, nelayan yang hanya berorientasi jangka pendek sering melakukan kegiatan pemanfaatan yang bersifat merusak lingkungan, seperti penggunaan bom, potassium dan sebagainya, umumnya nelayan ini orientasinya pada pasar, konflik ini dikatakan sebagai konflik horizontal yang tidak didasarkan pada kelas. c. Konflik

${ }^{6}$ Arif Satria. et.al. Menuju Desentralisasi Kelautan. Cidesindo. Jakarta. 2001.hal. 166 
agraria merupakan konflik yang terjadi akibat perebutan penguasaan fishing ground yang merupakan sumber mata pencaharian, konflik ini terjadi antar kelas nelayan maupun antar nelayan secara umum, biasanya terjadi antar nelayan dengan latar belakang daerah yang berbeda. d. Konflik primordial merupakan konflik yang terjadi akibat perbedaan identitas atau sosial budaya, antara lain etnik dan asal daerah. Konflik ini sering kali dipicu sebagai akibat diterapkan otonomi daerah dan pemahaman tentang otonomi daerah dipahami secara sempit, namun jika ditelusuri lebih mendalam, konflik identitas tersebut tidak bersifat murni melaikan tercampur dengan konflik-konflik lainnya yang juga sering terjadi jauh sebelum adanya otonomi daerah.

Dari beberapa konflik yang disampaikan diatas baik yang telah terjadi maupun akan terjadi perlu diantisipasi sedini mungkin guna mencegah terjadinya permasalahan yang lebih fatal, peran pemerintahan daerah dan kelembagaan dalam meminimalisir permasalahan yang berakibat konflik secara luas sangat penting dilakukan khususnya dalam meminimalisir konflik pengelolaan dan pemanfaatan sumberdaya perikanan di provinsi Kalimantan utara dan sekitarnya.

\section{G. Upaya Pemerintah Daerah Provinsi Kalimantan Utara dalam meminimalisir Konflik Pengelolaan Sumberdaya Perikanan}

\section{Upaya mencegah konflik antar Pemerintah Daerah.}

Satu diantara upaya mencegah terjadinya konflik antar pemerintah daerah yang dilakukan oleh Pemerintah Provinsi Kalimantan Utara, baik melalui instansi teknis Dinas Kelautan dan Perikanan Provinsi Kalimantan Utara maupun unsur pemerintahan daerah Kab/kota, diantaranya :

a. Pembentukan Forum Silaturahmi antar pemerintah daerah kabupaten/kota sewilayah utara provinsi Kalimantan Utara ; forum ini dibentuk sebagai forum diskusi antar kabuapten/kota yang membahas isu-isu strategis diwilayah utara provinsi Kalimantan Utara, nasional maupun internasional, didalam forum ini juga diangkat terkait isu-isu atau permasalahan tentang pengelolaan dan pemanfaatan sumberdaya perikanan serta pengelolaan wilayah laut yang saling berbatasan maupun wilayah laut kabupaten yang tidak berbatasan akan tetapi dimanfaatkan sumberdaya perikanannya oleh masyarakat daerah kabupaten/kota tertentu. Kabupaten/kota yang terlibat dalam forum silaturahmi ini terdiri dari Kota Tarakan, Kabupaten Bulungan, 
Kabupaten Nunukan, Kabupaten Malinau, Kabupaten Tana Tidung dan Kabupaten Berau (provinsi Kalimantan Timur).

b. Kerjasama dan Kesepakatan antar kabupaten/kota dalam upaya mencegah berbagai konflik antar daerah atau konflik masyarakat akar rumput khususnya nelayan, pemerintah daerah melakukan upaya kerjasama dan penandatanganan kesepakatan antar pemerintah kota dengan kabupaten sekitarnya. Terkait kerjasama yang telah disepakati diantaranya :

- Kesepakatan yang di fasilitasi pemerintah Provinsi Kalimantan Utara dengan Pemerintah Kab/kota dalam upaya pengamanan wilayah perairan khususnya pengamanan tambak dengan menyisikan anggaran untuk operasioanal pengawasan dan sarana/prasarana pengawasan.

- Kesepakatan antar pemerintah kota Tarakan dengan kabupaten Bulungan, kabupaten Nunukan, kabupaten Tanah Tidung, Provinsi Kalimantan Utara dan Kementerian Kelautan dan Perikanan Republik Indonesia dalam rangka penerapan Peraturan Menteri Kelautan dan Perikanan Republik Indonesia tentang penggunaan alat penangkap ikan pukat hela di perairan Kalimantan Utara. iii. Kesepakatan antara pemerintah kota Tarakan dengan kabupaten Tanah Tidung terkait dengan batas wilayah perairan yang difasilitasi pemerintah Provinsi Kalimantan Utara.

\section{Upaya meminimalisir konflik antar nelayan}

Konflik pengelolaan sumberdaya perikanan disebabkan oleh pemanfaatan sumberdaya perikanan maupun pemanfaatan ruang wilayah laut, khususnya diwilayah kewenangan pemerintah daerah provinsi Kalimantan utara, jauh sebelum penetapan UU otonomi daerah konflik pemanfaatan sumberdaya perikanan sudah sering terjadi diantara timbulnya konflik akibat tumbang tindih lokasi penangkapan antara nelayan berjenis alat tangkap pukat dengan alat tangkap pancing dan sejenisnya (rawai) antara nelayan kab/kota, maupun dengan nelayan kabupaten atau nelayan berasal dari luar provinsi lainnya, permasalahan utamanya daerah tempat penangkapan. Seiring meningkatnya teknologi dan peningkatan penangkapan sehingga nelayan tidak lagi terfokus pada satu wilayah tertentu, konflik perebutan wilayah tersebut berkurang, bahkan hamper menghilang. Permasalahan kembali timbul akibat di izinkannya alat tangkap ikan pukat hela, yang dapat beroperasi diwilayah perairan 1 (satu) mil keatas, 
sehingga kondisi member peluang konflik antara nelayan kecil/tradisional dengan nelayan pukat hela, dengan kata lain nelayan pukat hela lebih mampu dan dapat menjangkau daerah laut yang lebih luas, dibandingkan nelayan tradisional dengan sarana prasarana terbatas.

Salah satu upaya meminimalisir konflik tersebut melalui kesepakatan antar kabupaten/kota diwilayah utara Provinsi Kalimantan Utara, yang difasilitasi Pemerintah Daerah Provinsi Kalimantan Utara dalam bentuk Kesepakatan tentang penggunaan alat penangkap ikan pukat hela diperairan Kalimantan Utara. Selanjutnya untuknya kesepakatan tersebut menjadi rujukan dikeluarkannya Peraturan Gubernur Provinsi Kalimantan Utara atau peraturan daerah tentang penggunaan alat penangkap ikan pukat hela di perairan Provinsi Kalimantan Utara

\section{Penutup}

\section{Kesimpulan}

Berdasarkan hasil penelitian dan pembahasan pada uraian sebelumnya, peneliti membuat kesimpulan sebagai jawaban atas rumusan masalah yang dijadikan isu dalam penelitian ini. Pertama, Kewenangan Pemerintah Daerah dalam mengelola sumberdaya perikanan yang dilakukan oleh Pemerintah Provinsi Kalimantan Utara belum sepenuhnya dilakukan sesuai dengan kewenangannya, hal ini tergambar dari kegiatan yang dilakukan yang diorientasikan pada upaya memperoleh Pendapatan Asli Daerah (PAD) dengan pungutan retribusinya melalui kegiatan perizinan usaha perikanan sehingga belum terdapat konsep pengelolaan sumberdaya perikanan yang jelas, tepat dan terpadu.

Kewenangan Pemerintah Daerah dalam mengelola sumberdaya perikanan yang dilakukan oleh Pemerintah Provinsi Kalimantan Utara belum sepenuhnya dilakukan, khususnya dalam pengawasan dan penegakan hukum dalam memanfaatan sumberdaya perikanan.

Kedua, Upaya meminimalisir konflik yang dilakukan dengan menerapkan peraturan dan kesepakatan hanya upaya yang bersifat instan dan tidak pada substansi masalah masyarakat nelayan dan pemanfaatan sumberdaya perikanan diwilayah laut secara terpadu dan berkelanjutan, kemungkinan adanya konflik dapat terjadi jika tidak dilakukan pengelolaan sumberdaya perikanan yang tepat dan terpadu.

\section{Saran}

Pertama, Didalam melaksanakan kewenangan pemerintah daerah diwilayah laut terkait dalam pengelolaan dan pemanfaatan sumberdaya perikanan hendaknya 
memperhatikan keadilan dan kepastian hukum bagi nelayan tradisionalal/kecil, yang diberikan kebebasan menangkap diperairan manapun di Indonesia namun tidak didukung sarana prasarana yang memadai serta seringnya nelayan modern (wilayah, alat tangkap, ukuran kapal telah diatur) memasuki wilayah perairan penangkapan nelayan tradisional. kedua, Pemerintah daerah hendaknya melaksanakan dan menata kewenangannya dalam bentuk pengaturan dan penataan kewenangan yang lebih khusus dalam mengelola sumberdaya perikanan sesuai dengan kondisi dan potensi daerah namun tidak memecah urusan menjadi urusan wajib dan urusan pilihan, hal ini menggambarkan daerah kurang diberikan keluwesan didalam melakukan urusannya.

\section{REFERENSI}

Abdurrahmansyah D. 2009. Pengembangan Unit Penangkapan Ikan Unggulan di Kabupaten Bima [Skripsi]. Bogor: Fakultas Perikanan dan Ilmu Kelautan, Institut Pertanian Bogor. 67 halaman.

Akbarsyah. Serial Risalah Kota Tarakan, Tarakan Menghimbau, Tarakan:Pemerintah Daerah kota Tarakan, 2001.

Arif Satria,. et.al. Acuan Singkat Menuju Desentralisasi Pengelolaan Sumberdaya Perikanan, diterbitkan atas kerjasama Pusat Kajian Agraria IPB, Partnership Governance Reform Indonesia dengan PT. Pustaka Cesindo, Jakarta : Pustaka Cesindo, 2002.

. Menuju Desentralisasi Kelautan, diterbitkan atas kerjasama Pusat Kajian Agraria IPB, Partnership Governance Reform Indonesia dengan PT. Pustaka Cesindo, Jakarta : Pustaka Cesindo, 2002.

Bappeda dan Universitas Mulawarman. Startegi Penangulangan Kemiskinan Daerah Kota Tarakan Tahun 2011-2015. Bappeda. Tarakan, 2011

Badan Perencanaan Pembangunan Daerah Kota Tarakan kerjasama dengan Badan Pusat Statistik Tarakan. Profil Sosial Ekonomi Wilayah Pesisir Kota Tarakan, Tarakan : 2000.

Balai Besar Riset Sosial Ekonomi Kelautan dan Perikanan. Dinamika Pengelolaan Sumber Daya Kelautan dan Perikanan, Bunga Rampai Hasil-Hasil Riset,Badan Riset Kelautan dan Perikanan Departemen Kelautan dan Perikanan Republik Indonesia, Jakarta : 2007.

Dinas Kelautan dan Perikanan Kota Tarakan. Laporan Statistik Perikanan Kota Tarakan Tahun 2009, Tarakan, 2010. 
Laporan Tahunan Dinas Kelautan dan Perikanan Kota Tarakan.

Tarakan.2010.

Direktorat Jenderal Pesisir dan Pulau Pulau Kecil Departemen Kelautan dan Perikanan, Naskah Akademik Pengelolaan Wilayah Pesisir, Jakarta, 2001.

Dinas Komunikasi dan Informasi Kota Tarakan. Tarakan Toward New Singapore Tarakan Bumi Paguntaka. Diskoimfo Tarakan.2011

Hasan, Said. 2004. Analisis Potensi Retribusi Daerah Dalam Mengoptimalkan Penerimaan Daerah di Kabupaten Indragiri Hilir [Tesis]. Bogor: Sekolah Pasca Sarjana, Institut Pertanian Bogor.

Herjanto E. 2007. Manajemen Operasi. Jakarta: PT. Grasindo. 488 halaman.

Hermawan, Dede. 2009. Peningkatan Pengelolaan Pangkalan Pendaratan Ikan Pangandaran dan Wisata Pantai dalam Meningkatkan Kesejahteraan Nelayan [Tesis]. Bogor: Sekolah Pasca Sarjana, Institut Pertanian Bogor.

Isnaniah. 2009. Pengembangan Perikanan Tangkap Berbasis Sumberdaya Ikan Demersal di Perairan Kota Dumai Provinsi Riau [Tesis]. Bogor: Sekolah Pascasarjana, Institut Pertanian Bogor. 81 halaman.

Kramadibrata S. 2002. Perencanaan Pelabuhan. Bandung: Institut Teknologi Bandung. 471 halaman.

Laka, Fransiskus. 2003. Arahan Lokasi dan Strategi Pengembangan Tempat Pelelangan Ikan di Kawasan Pesisir Utara Kabupaten Sikka-Nusa Tenggara Timur [Skripsi]. Semarang: Fakultas Teknik, Universitas Diponegoro.

Lubis E. 2006. Pengantar Pelabuhan Perikanan Buku 1. Bogor: Bagian Pelabuhan Perikanan Departemen Pemanfaatan Sumberdaya Perikanan Fakultas Perikanan dan Ilmu Kelautan Institut Pertanian Bogor. 115 halaman. 2010. Pelabuhan Perikanan. Bahan Kuliah Pelabuhan Perikanan.Bagian Kepelabuhanan Perikanan dan Kebijakan Pengelolaan Pemanfaatan Sumberdaya Perikanan. Jurusan PSP FPIK IPB. Bogor.

Marhaeni Ria Siombo . Hukum Perikanan Nasional dan Internasional, Jakarta : Gramedia Pustaka Utama, 2010.

M. Marwan dan Jimmy. P. Kamus Hukum., Surabaya : Reality Publisher, 2009.

Novianti. 2008. Keberadaan Fasilitas Kepelabuhanan dalam Menunjang Aktivitas PPI Tanjungsari, Kabupaten Pemalang, Jawa Tengah [Skripsi]. Bogor: Fakultas Perikanan dan Ilmu Kelautan, Institut Pertanian Bogor. 134 halaman.

Nurani, Tri Wiji. 2002. Proses Hierarki Analitik (Analytical Hierarchy Process) "Suatu Metode untuk Analisis Kebijakan Pengelolaan Sumberdaya Perikanan dan 
Kelautan". Bahan Kuliah Riset Operasi Penangkapan Ikan. Laboratorium Sistem dan Optimasi Perikanan Tangkap. Jurusan PSP FPIK IPB.

Peter Mahmud Marzuki, Penelitian Hukum, Jakarta : Kencana, 2006.

Peter Salim dan Yeni Salim. Kamus Bahasa Indonesia Kontemporer, Jakarta : Modern English Press, 2002.

Rokhmin Dahuri, et.al. Pengelolaan Sumber Daya Wilayah Pesisir dan Lautan secara Terpadu,Jakarta : Pradnya Paramita, 2001.

Ronny Hanitijo Soemitro . Metodologi Penelitian Hukum dan Jurimetri. Jakarta : Ghalia Indonesia. 1994.

Saaty, Thomas L. 1991. Pengambilan Keputusan "Proses Hirarki Analitik untuk Pengambilan Keputusan dalam Situasi yang Kompleks. Jakarta : PT Dharma Aksara Perkasa.

Sasmita S, Widodo. 2007. Sebaran Alat Penangkap Ikan Di Wilayah Pengelolaan Perikanan Indonesia. Semarang: BPPI. 68 halaman.

Simanjuntak STO. 2005. Kajian Fasilitas dan Fungsi Pangkalan Pendaratan Ikan (PPI) Pasir dalam Menunjang Kegiatan Perikanan Tangkap Di Kabupaten Kebumen, Jawa Tengah [Skripsi].Bogor: Fakultas Perikanan dan Ilmu Kelautan, Institut Pertanian Bogor. 68 halaman.

Sinungan M.2008.Produktivitas Apa dan Bagaimana. Jakarta: Bumi Aksara.154 halaman.

Subani W, Barus HR.1989.Alat Tangkap Ikan dan Udang Laut di Indonesia. Jurnal Penelitian Perikanan Laut. No. 50. 248 halaman.

Suparto Wijoyo. Otoda dari mana dimulai ?, Surabaya : Airlangga University Press, 2005.

Supriadi dan Alimuddin. Hukum Perikanan Indonesia. Sinar Grafika, Jakarta. April 2011. Syukur LD. 1991. Analisis Produktivitas Nelayan dan Produktivitas Alat Penangkapan Ikan di Kabupaten Buton-Sulawesi Tenggara [Skripsi]. Bogor: Fakultas Perikanan dan Ilmu Kelautan, Institut Pertanian Bogor. 64 halaman.

Walpole RE. 1992. Pengantar Statistika Edisi ke-3. Jakarta: PT. Gramedia Pustaka Utama. 515 halaman.

Zainuddin Ali. Metode Penelitian Hukum, Jakarta : Sinar Grafika, 2010.

Zainun B. 2001. Manajemen Sumberdaya Manusia Indonesia. Jakarta: Gunung Agung. 143 halaman. 